\title{
The impact of selected food additives on the gastrointestinal tract in the example of nonspecific inflammatory bowel diseases
}

\author{
Sara Jarmakiewicz-Czaja ${ }^{1}$, Dominika Piątek2 ${ }^{2}$ Rafał Filip ${ }^{3,4}$
}

\begin{abstract}
${ }^{1}$ Institute of Health Sciences, Medical College of Rzeszow University, Rzeszow, Poland ${ }^{2}$ Department of Conservative Dentistry with Endodontics, Medical University of Lublin, Lublin, Poland

${ }^{3}$ Department of Gastroenterology with IBD, Unit of Clinical Hospital 2, Rzeszow, Poland ${ }^{4}$ Medical College of Rzeszow University, Rzeszow, Poland
\end{abstract}

Submitted: 9 January 2020; Accepted: 6 July 2020

Online publication: 8 January 2021

Arch Med Sci 2022; 18 (5): 1286-1296

DOI: https://doi.org/10.5114/aoms/125001

Copyright $\odot 2020$ Termedia \& Banach

\begin{abstract}
Various types of food additives are widely used in the food industry. Due to their properties extending the usefulness for consuming food products, they give them different colours, consistency, or taste. The products are marked ' $E$ ' and the code is assigned to the subscription used. Many of the supplements affect human health negatively. Emulsifiers or stabilizers can lead to epithelial loads and the development of inflammation. Sucrose and other sweeteners may change the composition of the intestinal microflora and thus lead to intestinal blockage. Some additives classified as preservatives are available and may predispose to intestinal dysbiosis. Available substances belonging to food dyes may predispose to genotoxic and cytotoxic effects and cause inflammation in the intestines. Substances added to food can also cause disorders of intestinal homeostasis.
\end{abstract}

Key words: Crohn's disease, ulcerative colitis, food additives.

\section{Introduction}

Inflammatory bowel diseases (IBD) are associated with a chronic course and a complex aetiology that is not fully understood. They are characterized by periods of disease activity and remission. In Crohn's disease (CD), inflammation can occur along the entire length of the digestive tract. The diseased sections are separated by healthy fragments. Exacerbation is most often manifested by diarrhoea with an admixture of mucus and blood, abdominal pain, fever, weight loss. Fistulas and abscesses are common complications. In ulcerative colitis (UC), the disease is located in the rectum and/or large intestine, most often in the colon. The disease symptoms in UC are similar to those in CD, including diarrhoea with blood and mucus, and painful bowel movements. A late complication of both UC and colonic CD may be colorectal cancer [1, 2].

\section{Pathogenesis of inflammatory bowel diseases}

Numerous studies have proven that the underlying cause of IBD may be inadequate functioning of the immune system in correlation with a genetic predisposition and the presence of environmental triggers [3, 4] (Figure 1).

\author{
Corresponding author: \\ Sara Jarmakiewicz-Czaja \\ Medical College \\ of Rzeszow University \\ Institute of Health Sciences \\ Rzeszow, Poland \\ E-mail: \\ sara.jarmakiewicz@gmail.com
}


One of the factors that significantly affects the occurrence of IBD is smoking [5]. In numerous works, the authors agree on smoking as a protective factor in UC [6]. Ananthakrishnan found in his study that smoking can increase the risk of $C D$ by up to two times [4]. In addition, smoking in $C D$ can worsen the course of the disease. Some researchers present a significant relationship between smoking cessation in UC and the severity of disease risk. However, they do not find such a relationship in CD. Ananthakrishnan et al. also described a link between IBD development and environmental pollution [7]. In their research, Lochhead et al. and Opstelten et al. did not confirm this relationship [8,9]. Antibiotics are another factor that belongs to the group of environmental triggers. Kronman et al. observed a positive correlation with antibiotic therapy used in children and the occurrence of IBD; however, more indepth studies are required in this field [10].

\section{Intestinal homeostasis}

The preservation of intestinal homeostasis requires proper functioning of the intestinal barrier, which consists of intestinal epithelium, immune cells and intestinal microbiota.

The intestinal epithelium is formed of various cells such as enterocytes, goblet cells, Paneth cells, tuft cells, enteroendocrine cells, and $M$ cells (microfold cells) [11].

It is separated from the intestinal lumen by a layer of mucus, islanded by specialized goblet cells which constitute the first line of defence. Goblet cells also partake in the transport and presentation of antigen to dendritic cells (CDs). The small intestine is provided with a single layer of mucus while that in the colon is divided into several portions. The mucus adhering directly to epithelial cells mainly forms a glycocalyx consisting primarily of MUC2 (mucin 2-oligomeric mucus gel-forming), and it blocks bacterial entry [12]. In their study on animal models, Liso et al. observed that a mutation in the MUC2 gene which causes abnormal MUC2 synthesis thereby reduces mucus and leads to intestinal dysbiosis and predisposes to colitis [13]. On the other hand, the outer part of mucus is of low density and rich in immunoglobulins. It forms a habitat for mucolytic bacteria such as Akkermansia muciniphila, Bacteroides thetaiotaomicron and Bacteroides fragilis [14-18]. Parikh et al. observed that in UC, a protein with antimicrobial activity (WAP Four-Disulfide Core Domain 2 - WFDC2) secreted by goblet cells causes mucus defects by reducing its expression [19]. Furthermore, in patients with UC, the mucus layer may decrease and factors inducing goblet cell differentiation may be induced. Often, phosphatidylcholine (PC) is decreased in the mucus of pa-

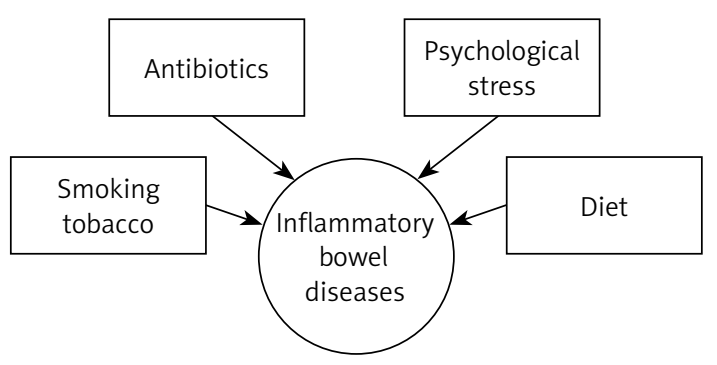

Figure 1. Environmental triggers that may predispose to inflammatory bowel diseases [4]

tients, which is a major phospholipid of plasma membranes (up to 70\%) [20]. The presence and proper bacterial composition of the intestine is essential for the proper functioning of the mucus layer of the colon. An example could be Bacteroides thetaiotaomicron, which has a beneficial effect on goblet cell differentiation; therefore intestinal dysbiosis seen in IBD can have a direct effect on mucus secretion [21].

The intestinal epithelium is not only a physical barrier, but also participates in the body's immune response. Here, macrophages, dendritic cells (DCs) and lymphocytes are involved. Toll-like receptors (TLR) located on the cell surface or in endosomes, as well as cytosolic receptors such as NLRs (nucleotide oligomerization domain-like receptors) and RLRs (acid-inducible gene I receptor) are responsible for the distribution of molecular patterns of microorganisms, retinoic acid-retinoic acid inducible gene-I-like receptor) [22-24]. Caer et al. present the major role of mononuclear phagocytes (monocytes, dendritic cells, macrophages) - mononuclear phagocytes (MNPs) in maintaining normal intestinal homeostasis. This is due to immunological tolerance to commensal microorganisms and to food-derived antigens. Furthermore, MNPs induce the body's immune response to pathogens [25]. As specialized cells that present antigen to $T$ lymphocytes, DCs play a major role in the body's immune response. DC and macrophages phagocytose particles from the environment, e.g. apoptotic epithelial cells [26]. Natural killer (NK) cells are an important factor regulating intestinal homeostasis. These cells belong to the lymphocyte group and exhibit direct (cell lysis) and indirect cytotoxic activity (with the participation of cytokines, e.g. TNF- $\alpha$, IFN- $\gamma$, IL-10). Their action is the result of regulation of activation factors (e.g. CD94/NKG2 lectin receptors) and inhibition factors (e.g. killer cell immunoglobulin-like receptors - KIR). Decreased MHC (major histocompatibility complex) class I expression activates NK cells, thereby in some way complementing the $T$ cell immune response [27]. Due to the $T$ cell receptor (TCR), NKT cells are divided into NKT/iNKT type I and NKT type II. INKT cells can regulate the commensal microflora. 
Deficiency of CD1d (protein presenting lipid antigens to $T$ lymphocytes) and regulation of intestinal microflora iNKT may cause an increase in the number of commensal microorganisms in the small intestine, by reducing the secretion of antimicrobial peptides (AMPs). By releasing $\mathrm{AMP}$ and controlling cell function, Paneth CD1d and NKT can monitor the composition of the intestinal microflora. This is particularly important for IBD [28].

Another factor to maintain intestinal homeostasis is the preservation of a proper intestinal microbiome.

The human body contains ca. $10^{14}$ microorganisms [29]. The intestinal microbiota comprises bacteria, archaea, viruses and eukaryotes [30]. In a healthy host, the gut microflora is diversified and displays a symbiotic activity between the human body and the population of bacteria living in the intestine. Healthy intestinal microbiota consists primarily of the bacteria Firmicutes, Bacteroidetes, Actinobacteria and Proteobacteria [31]. Maintenance of intestinal homeostasis depends on the factor that affects the intestines, its pathogenicity, and the location affected by the factor. Changes in the proportion of commensal and pathogenic bacteria that live in the intestines also have a significant role in impairing the intestinal barrier, and thus the maintenance of intestinal homeostasis [32]. Lin and Zhang discuss the role of intestinal microflora and its metabolites in maintaining homeostasis, suggesting that commensal microorganisms could regulate the responses of $T$ cells and in addition strengthen the mucosal barrier. Furthermore, some bacteria metabolise food to produce butyrate, which is a medium for enterocytes and colonocytes [33]. Due to the reduction of the commensal bacterial flora, patients with IBD experience a decrease in $\alpha$-defensins (antimicrobial peptide) and an increase of REGIIl (regenerating islet-derived protein III- $\gamma$ ). REGIIl $\gamma$ is an antibacterial lectin produced by epithelial cells in the small intestine; its role is to limit the growth of Gram-positive bacteria on the mucosal surface [34]. Schultz et al. indicate that increasing REGIIly may have a compensatory effect of reducing $\alpha$-defensins in IBD patients [35]. Swidsinski et al. report that patients with IBD have a significant increase in bacteria that penetrate deep into the mucus [36]. Moreover, changes in the functions of ATG16L1 (autophagy-related gene 16 like 1) and IRGM (protein immunity related GTPase $M$ ) can cause the growth of Escherichia coli in patients [37]. They are also often found with a decrease in the population of bacteria that produce SCFAs (short chain fatty acids) from indigestible carbohydrates, which causes an immune response disorder [38, 39].
Zhang et al. report that a modification of diet (57\%) has the greatest effect on intestinal microbiota changes and thus on homeostasis [40]. Usually, homeostasis disorders are attributed to macronutrients such as carbohydrates, proteins or fats, while food additives are of equal importance $[41,42]$. Zeng et al. have widely described the pathomechanism of occurrence of intestinal microflora disorders. One of the most interesting questions is dysbiosis caused by increasing the amount of Enterobacteriaceae, which could predispose to the occurrence of numerous diseases. Enterobacteriaceae develop with increased amounts of oxygen in the intestines and thus the growth of anaerobic bacteria Clostridia and Bacteroidia is inhibited. In inflammation of the intestine, this is caused, among other factors, by the activation of intestinal epithelial enzymes produced by reactive forms of oxygen [43].

\section{Mechanism of action of additives on colon}

One of the proposed hypotheses of the mechanism of action of emulsifiers is to limit the proper functioning of the mucosal barrier by increasing bacterial translocation from the distal part of the ileum. Translocation occurs through M cells, increasing their uptake and in the villi epithelium, which leads to inflammation of the intestine. Due to rupture of the mucosal barrier after administration of polysorbate 80, Chassaing et al. observed in animal models a much larger number of bacteria adhering to the colon [44, 45]. Pereira et al. came to similar conclusions by studying the effect of food additives on the intestinal permeability of human cell cultures (Figure 2) [45-47].

\section{Impact on food additives on development of inflammatory bowel diseases}

Due to the amount of food additives that are used in the food industry, their direct impact on the occurrence of UC and CD is still studied. Nevertheless, the literature presents examples that appear to be relevant to the aetiology of IBD. One study assessing the association with titanium dioxide and the risk of IBD was presented by Hummel et al. They examined 88 children with IBD and 63 from a healthy control group for intestinal pigment, consisting mainly of aluminosilicate and titanium dioxide. They found that patients with CD had significantly less pigment compared to the other groups. This may have been the result of disturbed macrophage autophagocytosis, which predisposed to induce inflammation [47]. Urrutia-Ortega et al. observed in animal models that $\mathrm{TiO}_{2}$ can reduce the number of goblet cells in the colon and cause dysplastic changes, which can affect the normal function of the intestinal barrier [48]. 


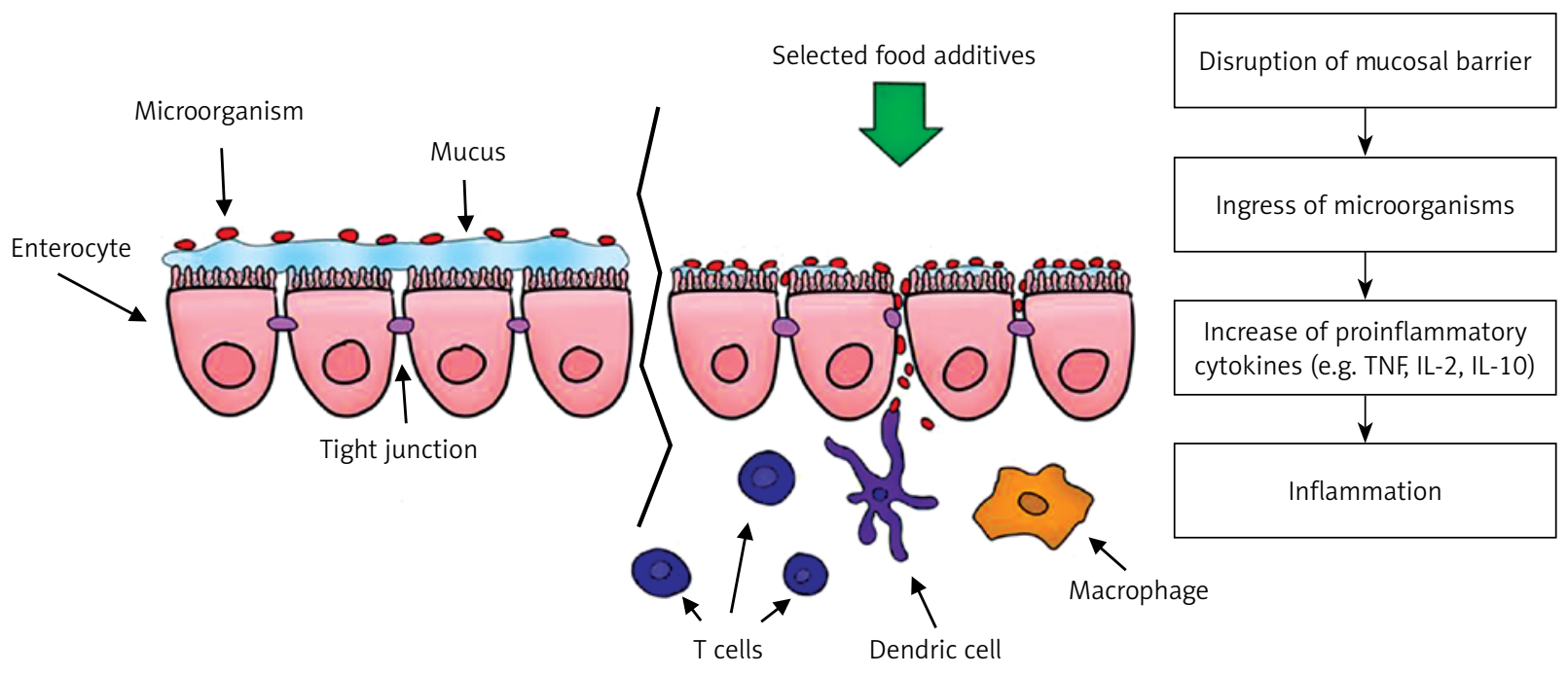

Figure 2. The effect of selected food additives on the colon [45-47]

Jimenez Loayza et al. studied the effects of food additives such as saccharin, sucralose, polysorbate 80 , and sodium sulfite on the bacterium Faecalibacterium prausnitzii, which has protective effects and can alleviate inflammation. The researchers found that sodium sulfite and polysorbate 80 inhibited the bacteria, and thus the additives could predispose to intestinal homeostasis disorder. The authors also recommended exclusion of these substances from the diet to prevent CD [49]. Martino et al. presented the effect of CMC and carrageenans on inducing inflammation in the intestines predisposing to IBD. Carrageenan causes disturbances in 2O-1 expression, which disturbs the tight junction function and thus may lead to interruption of the intestinal barrier and penetration of microorganisms and increased secretion of proinflammatory cytokines. In addition, the substance affects the action of DMBT1 (deleted in malignant brain tumors 1 protein), which in turn leads to an inadequate immune response to bacteria and viruses [50]. Borthakur et al. also analysed the effects of carrageenan on inflammation in the intestines. They concluded that carrageenan affects the activation of $\mathrm{Bcl} 10$ (the gene encoding the B-cell lymphoma/leukemia 10 protein), which increases the amount of NF- $\kappa B$ in the colon cells, and thus determines the increase in IL- 8 production. The authors also describe Bcl10, which may be associated with enteritis (Table I [51-63]).

Further research is needed to confirm the effect of food additives on the development of intestinal homeostasis disorders and a predisposition to IBD. However, given current research into food additives that often exacerbate inflammation, patients should be educated in choosing foods that do not contain substances that could adversely affect the course of the disease.

\section{Food additives}

Food additives are defined as substances that are intentionally added to food in a technological process and are not consumed alone as food [64].

\section{Emulsifiers, stabilizers, thickeners}

Emulsifiers are surface-active substances that lead to the mixing of water and fat and the formation of an emulsion. It can be formed due to the hydrophilic and lipophilic structure of the emulsifier. Thanks to this structure, it attracts water as well as fats. They occur in natural and synthetic forms. In food products they are marked with symbols from E400 to E499 and are mainly found in highly processed foods. These substances are designed to homogenise the appearance of the product and extend its shelf life. In recent years, many scientists have been studying the relationship between the consumption of products that contain emulsifiers and their effect on the digestive tract $[65,66]$. Chassaing et al. found in their study conducted on mice that emulsifiers can cause disturbances in the composition of the intestinal microflora, which in turn can lead to enteritis and the development of metabolic syndrome. In the study, rodents were fed with carboxymethyl cellulose (CMC), which in the food industry is designated as E466, and polysorbate-80 (P80) - E433. The authors also stated that it is necessary to conduct research on the reconstruction of the "healthy" host microbiome. They also suppose that it is not enough to exclude food containing stabilizers from the diet, but 
Table I. Selected food additives that may cause enteritis and predispose to inflammatory bowel diseases

\begin{tabular}{|c|c|}
\hline Example of food additive & Effects on enteritis \\
\hline Titanium dioxide (E171) & $\begin{array}{l}\text { - Activation and exacerbation of inflammation through the secretion of IL-18 } \\
\text { and IL-1 } \beta \text { ( } \mathrm{TiO}_{2} \text { absorbed by phagocytic cells }->\text { combining caspase-1 and NLRP3 } \\
\text { - > cytokine secretion) [52] } \\
\text { - Causing microinflammation in the colon mucosa that promotes precancerous } \\
\text { changes (E171 accumulates in Payer's patches -> increased DC activity) [53] } \\
\text { - Increased ROS (reactive oxygen species) production and increased intestinal } \\
\text { barrier permeability [54] } \\
\text { - Reduced SCFA and reduced MUC2 (in animal models) -> disturbed intestinal } \\
\text { homeostasis, increased immune cell activity and increased production } \\
\text { of proinflammatory cytokines [55] }\end{array}$ \\
\hline Carboxymethyl cellulose (CMC) & - Change in mucus structure and thickness -> bacterial translocation -> enteritis [58] \\
\hline Maltodextrin (MDX & $\begin{array}{l}\text { - Increase in IL-1 } \beta \text { and Lcn-2 (lipocalin-2), susceptibility to intestinal damage } \\
\text { by activating the ER pathway (endoplasmic reticulum) in the intestinal } \\
\text { epithelium, changes in the intestinal barrier by reducing MUC2 expression } \\
\text {-> increasing susceptibility to enteritis [59] }\end{array}$ \\
\hline Carrageenan (E407) & 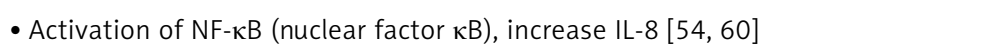 \\
\hline Sucralose & - Intestinal dysbiosis -> promotes the induction of inflammation $[61,62]$ \\
\hline Saccharin & $\begin{array}{l}\text { - Caco- } 2 \text { cells by activating NF- } \kappa B \text {, which leads to a change in claudin-1 function } \\
\text {-> intestinal barrier disorder }->\text { inflammation [63] }\end{array}$ \\
\hline
\end{tabular}

additionally probiotics and prebiotics should be introduced to rebuild the normal intestinal microflora [44]. Viennois et al. also demonstrated that food emulsifiers directly affect the intestinal microbiome by changing the expression of bacterial genes, increasing their pro-inflammatory activity [67]. In their subsequent study, Chassaing et al. clearly described the negative effects of emulsifiers on the gastrointestinal tract. The use of foods rich in these supplements may be associated with an increase in pathogenic microorganisms, their translocation and the development of inflammation in animal models [68]. Glade et al. described the widespread use of carboxymethylcellulose in the food industry, at the same time highlighting its adverse effect by weakening the intestinal barrier, which may increase the body's predisposition to inflammatory episodes [69]. Swidsinski et al. came to similar conclusions during a study on CMC in animal models. They administered mice a $2 \%$ CMC solution orally and water to the control group for 3 weeks. Bacterial overgrowth and small intestinal inflammation were demonstrated in the study group [70]. Roca-Saavedra et al. stated that emulsifiers (polysorbate-80) could contribute to the translocation of Escherichia coli (even up to 59-fold increase), due to which intestinal homeostasis is disturbed [71]. Gillois et al. described the formation of intestinal barrier disorders caused by, among other substances, certain emulsifiers and nanomaterials commonly used in food [14]. Roberts et al. reported finding a correlation between consumption of food rich in emulsi- fiers and the incidence of CD. They also observed displacement of bacteria through the intestinal epithelium [72]. Even consumption of low doses of emulsifiers with food can lead to damage to the intestinal epithelium [73].

In their papers, many researchers cite the negative effects of emulsifiers commonly found in food. They agree that in animal models there is a correlation between consuming these ingredients in the diet and the development of inflammation, e.g. in the colon. However, they also stress that further research is needed in this area in patients to determine the dose that has a negative impact on human health [74-77].

\section{Preservatives}

These are a group of substances belonging to the group of food additives. They are marked with symbols from E200 to E299. They are chemical compounds or a mixture of substances that are designed to limit the development of substances such as fungi, bacteria or viruses, thereby extending the shelf life of the food product. Many researchers describe the effect of preservatives on human health $[78,79]$.

Damas et al. demonstrated in their work the possibility of reducing intestinal inflammation by avoiding foods rich in preservatives [80] Ho et al. observed that chemicals used in processed foods could affect the development of IBD [5]. In their work, Hrncirova et al. studied the effect of food additive mixtures on the intestinal microflora. They colonized the previously sterilized 
bacterial flora of mice with microorganisms from healthy humans (human microbiota-associated HMA). Food additives were given to the animals at a level that corresponds to consumption in the European population. The mixture included potassium sorbate (E202), sodium benzoate (E211), and sodium nitrite (E250). The preservatives were shown to reduce the amount of Clostridiales and increase the Proteobacteria phylum, resulting in intestinal dysbiosis. In addition, the authors found a strong relationship between the NOD2 gene mutation and intestinal microflora disorders after administration of preservatives, compared to the group without such a mutation. The researchers also point out the need to study the effect of each of the above food additives on the intestinal microbiome separately [81]. Hrncirova et al. also investigated the sensitivity of some bacteria in the human intestinal microflora to preservatives. They observed that in many countries the consumption of this type of food additive is several times higher than the acceptable daily intake. They also demonstrated that the strains susceptible to both individual components (sodium benzoate, potassium sorbate, sodium nitrite) and their mixture are: $B$. coprocola, L. paracasei, B. longum. Strains sensitive to sodium nitrite and to mixtures of additives are $C$. tyrobutyricum and $H$. hepaticus [82]. Raposa et al. conducted a study involving E202, E211, and E250. They studied the effect of the above food additives on the expression of NF- $\mathrm{KB}$ (nuclear factor kappa-light-chain-enhancer of activated $\beta$ cells), MAPK8 (mitogen-activated protein kinase 8) and GADD $45 \alpha$ isolated from liver tissue. The preservatives were shown to be able to express MAPK 8 and GADD $45 \alpha$ depending on the dose [83].

\section{Colourings}

Colourings are substances whose purpose is to recreate the colour of a given food product or give it a new one. They can be of natural origin or made by chemical synthesis and are marked with symbols E100-E199. Colourings are added to almost every group of food product, from cereal products to fats, meat or fish to sugars, drinks and dietary supplements [84].

Research from Southampton is particularly important in the history of research into food colourings. It tested how tartrazine (E102), allura red (E129), quinoline yellow (E104), cochineal red (E124), orange yellow (E110) and azorubine (E122) affect behaviour in children. Increased hyperactivity, anxiety or reduced concentration were observed in the group [85]. Later studies in this area also yielded similar results.

In the light of current research, colourings commonly used in food may be associated with allergic reactions. Vojdani and Vojdani describe a strong relationship between tetrazine and the occurrence of asthma or urticaria in susceptible individuals. They also report that lymphocyte infiltration and partial atrophy of the intestinal villi after administration of tetrazine have been shown in animal models. Some colourings, e.g. allura red (E129), may cause angioedema or rhinitis [86]. In turn, in their study Zsila et al. describe the impact of colourings on human LL-37 peptide. LL-37 has antimicrobial activity, but also has an effect predisposing to the occurrence of certain diseases, e.g. UC or CD. The researchers added to LL-37 molecules, among others, Allura red or tartrazine, thanks to which the structure of the peptide was changed, which may affect its biological activity, and thus reduce the potential pathophysiological effect [87]. After carrying out a study in animal models, Dafallah et al. came to the conclusion that synthetic colourings used in food production have an adverse effect on the proper functioning of the liver and kidneys, and cause lipid metabolism disorders compared to natural food colourings [88]. Raposa et al., examining the effect of certain food additives on gene expression, discovered that tartrazine (E102) has a significant effect on the expression of NF-KB and MAPK8 [83].

Titanium dioxide, widely described in the literature and designated with the symbol E171, belongs to the group of colourings. Used in the production of chewing gum, ice cream, toothpastes and medicines, it gives the products a white colour. According to the European Food Safety Authority (EFSA), the average adult can consume 0.5 to $5.7 \mathrm{mg}$ of titanium dioxide per $\mathrm{kg}$ of body weight per day [89].

Sycheva et al. carried out one of the first studies to determine the genotoxicity of nano- and microparticles of titanium dioxide in mouse models. The compound was administered to the mice daily for 1 week at 40, 200 and 1,000 mg/kg of body weight. The study showed that the genotoxicity was associated with inflammation. Titanium dioxide increases the mitotic index, among others in the colon epithelium [90]. Proquin et al. came to similar conclusions. They showed that titanium dioxide has the ability to induce the production of ROS as well as genotoxic properties [91]. Another study has shown that in IBD patients titanium dioxide can activate inflammation through uptake, among others, by macrophages and activation of IL-1 $\beta$ and IL-18 [55]. Faust et al. observed in their in vitro study that exposure of tissue surface to E171 nanoparticles at $100 \mathrm{ng} / \mathrm{cm}$ caused microvilli loss [92]. Due to the different chemical structures of the colouring agents anatase, brucite and rutile, some researchers investigated them individually and their effects on health. Tada-Oikawa et al. noted that exposure to anatase at $50 \mu \mathrm{g} / \mathrm{ml}$ increases IL$1 \beta$ production by macrophages from the THP-1 cell 
line and increases IL-8 in Caco-2 cells [58]. Pinget et al. investigated the effect of E171 on the intestinal microbiome. The study was conducted on animal models that were administered titanium dioxide in water at doses of $0 \mathrm{mg}, 2 \mathrm{mg}, 10 \mathrm{mg}$ and $50 \mathrm{mg}$ per $\mathrm{kg}$ of body weight per day for 4 weeks. It was shown that the largest changes are observed after administration of $50 \mathrm{mg}$ of E171 through reduced short chain fatty acid (SCFA) production. MUC2 expression was reduced, while Defb3 (defensin $\beta 3$, which has antimicrobial activity as early as 3-4 h after exposure to bacteria), was increased. The researchers also observed a rise in the numbers of macrophages and Th17 lymphocytes and the amount of proinflammatory cytokines [93, 94]. $\mathrm{TiO}_{2}$ particle size is not a factor that affects cytotoxicity or the transport of colouring across the intestinal barrier [95]. Titanium dioxide may also alter the absorption of nutrients from food [96].

\section{Antioxidants}

Antioxidants used as food additives are marked with symbols E300-E399. Most of them display beneficial effects on health, among others protective against cardiovascular or neurodegenerative diseases [97]. However, some studies draw attention to propyl gallate (E310), butylhydroxyanisole (E320 - BHA) and butylhydroxytoluene $(\mathrm{E} 321-\mathrm{BHT})$ and their potential harmful effects [98]. These substances are synthetic antioxidants, most often added to food [99]. Propyl gallate (PG) is often used in the food industry to prevent rancidity of fat-rich products. Hamishehkar et al. observed that the food additive PG induces cell cytotoxicity and genotoxicity. Moreover, in the presence of $\mathrm{Cu}$ (II) PG may change its oxidizing properties into pro-oxidative [100]. Yang et al. concluded that PG causes disorders in the proper functioning of mitochondria [101]. BHA and BHT are chemical antioxidants. Carocho et al. consider that they may have harmful effects on health, but underline the necessity of further research into the topic [99].

\section{Flavour enhancers}

Flavour enhancers belong to the group of food additives marked with symbols E600-E699. Monosodium glutamate (E621) is one of the more frequently mentioned additives in this group. In their study, Holton et al. examined how monosodium glutamate (MSG) affects the occurrence of symptoms with diagnosed irritable bowel syndrome. They ascertained that exposure to this supplement in food can cause a relapse of IBS symptoms and thus degrade patients' quality of life [102]. Avuloglu-Yilmaz et al. investigated the effect of monopotassium glutamate (MPG) and magne- sium diglutamate (MDG) in vitro on human lymphocytes. They observed that the addition of MPG and MDG caused increased chromosomal aberrations and damage to the DNA strand; this was especially visible when using higher concentrations of substances [103].

\section{Food additives of various applications}

Sucrose is a compound belonging to the disaccharides. It is made of D-glucose and D-fructose molecules connected by a glycosidic bond. In the food industry, food sugar, whose main ingredient is sucrose, is made from sugar cane or sugar beet. Zeng et al. after a meta-analysis of studies detected a positive risk of $C D$ in correlation with high sucrose intake [104].

Racine et al. in their study of eating habits and their association with IBD revealed a relationship between the consumption of sugar and sweet non-alcoholic beverages and the occurrence of UC in patients who were characterised by low vegetable consumption. They also opined that further research in this area is necessary [105]. In a multi-centre study, Wang et al. conducted a case-control research over 3 years in 17 hospitals, which showed that UC patients were more likely to eat spicy foods and sugar compared to the control group [106]. In their next work they described a positive correlation of sucrose intake (10 g/day) with the risk of UC [107]. Bueno Hernández et al. also confirmed in their research the link between IBD and high sugar consumption by children [108].

Sucralose is another important food additive that can affect the development of IBD.

This is a food additive designated as E955. Sucralose is a sweetener, a derivative of sucrose. It is 600 times sweeter than sucrose through conversion of 3 hydroxyl groups to chlorine atoms. The ingredient is added to, among other things, "lite" products, some sweeteners, soft drinks, dietary supplements and jams [109].

Qin presents a relationship between the approval of sucralose for use in some countries and the increase in their incidence of IBD. He hypothesizes that saccharin and sucralose can cause a change in the intestinal microflora and damage the intestinal barrier by degrading mucus in the intestines [65]. Rodriguez-Palacios et al. conducted an animal model study in which a preparation containing sucralose and maltodextrin as filler was administered for 6 weeks. They found that the ingredient can cause an increase in Proteobacteria, which causes a change in the intestinal microflora. In addition, in individuals susceptible to enteritis, it may increase myeloperoxidase (MPO) activity, which may exacerbate inflammation [110]. Polyols such as sorbitol or xylitol consumed in large quantities may also increase intestinal 
dysbiosis or predispose to inflammation [111]. Cox et al. draw attention to the limitation of the use of fructans among IBD patients due to worsening of gastrointestinal symptoms such as abdominal pain, flatulence and diarrhoea. They also observed no significant exacerbation of symptoms after sorbitol administration. However, they stress the need for further research in this area, because the amount of the ingredient taken may be of major importance for the occurrence of ailments [112].

\section{Modified starches}

1,2-propylene glycol (E1520) is the most commonly described food additive in the group of modified starches. Using animal models for this purpose, Laudisi et al. proved that a diet rich in propylene glycol (E1520) may predispose to IBD due to hyperplasia of cells that produce mucus, which can change the intestinal microflora to an unfavourable one [113]. Propylene glycol is used as a preservative or emulsifier, but belongs to the group of modified starches. It appears in ready meals, biscuits and as an addition to medicines and cosmetics. González-Bermúdez, examining the effect of selected thickeners on the intestinal microflora of infants, have shown that maize hydroxypropylated distarch phosphate (Mhdp) could reduce intestinal $\mathrm{pH}$ and increase production of acetate. This type of action may limit the diversity of the intestinal microflora in early life [114]. Most food additives belonging to the group of modified starches are added as thickeners to confectionery, ready meals, flavoured yoghurts or dressings, which also contain other substances that have adverse effects on health. In addition, foods are often supplemented with maltodextrin (MDX), which is a product of partial depolymerization of starch [115]. Maltodextrin (MDX) has been the subject of research by Laudisi et al., who administered it in drinking water to mice as well as the endoplasmic reticulum (ER) stress inhibitor tauroursodeoxycholic acid (TUDCA) and observed that the susceptibility to inflammation after administration of MDX relates to the stress pathway ER/UPR. They showed that administration of a $5 \%$ MDX solution in combination with DSS or indomethacin can increase intestinal inflammation. The administration of MDX over a long period can maintain a reduced amount of mucus in the intestines, which predisposes to inflammation of the gut [62].

\section{Conclusions}

Food additives are commonly used to protect food from damage and ensure its proper taste and consistency. There are very few studies on the direct impact of food additives on the occurrence and course of IBD. However, selected substances added to food in the technological process can lead to dysbiosis of the intestinal microbiome, and thus predispose to inflammation. In the future, the role of metals and compounds used in the production of plastics for the food industry in the occurrence of intestinal homeostasis disorders should also be analysed. Despite the great progress in understanding the aetiology of IBD, the role of food additives is still not sufficiently understood. therefore further research is needed to assess the impact of these ingredients on the occurrence and course of IBD.

\section{Conflict of interest}

The authors declare no conflict of interest.

\section{References}

1. Torres J, Mehandru S, Colombel JF, Peyrin-Biroulet L. Crohn's disease. Lancet 2017; 389: 1741-55.

2. Collins P, Rhodes J. Ulcerative colitis: diagnosis and management. BMJ 2006; 333: 340-3.

3. Loddo I, Romano C. Inflammatory bowel disease: genetics, epigenetics, and pathogenesis. Front Immunol 2015; 6: 551.

4. Ananthakrishnan AN. Environmental risk factors for inflammatory bowel diseases: review. Dig Dis Sci 2015; 60: 290-8.

5. Ho SM, Lewis JD, Mayer EA, et al. Challenges in IBD research: environmental triggers. Inflamm Bowel Dis 2019; 25 (Suppl 2): S13-S23.

6. O'Toole A, Korzenik J. Environmental triggers for IBD. Curr Gastroenterol Rep 2014; 16: 396.

7. Ananthakrishnan AN, Bernstein CN, Iliopoulos D, et al. Environmental triggers in IBD: a review of progress and evidence. Nat Rev Gastroenterol Hepatol 2018; 15: 39-49.

8. Lochhead P, Hart JE, Ananthakrishnan A, Khalili H, Laden F, Chan AT. Air pollution and risk of inflammation bowel diseases. Gastroenterology 2018; 154 Suppl 1: S-20.

9. Opstelten JL, Beelen RMJ, Leenders M, et al. Exposure to ambient air pollution and the risk of inflammatory bowel disease: a European nested case-control study. Dig Dis Sci 2016; 61: 2963-71.

10. Kronman MP, Zaoutis TE, Haynes K, Feng R, Coffin SE. Antibiotic exposure and IBD development among children: a population-based cohort study. Pediatrics 2012; 130: e794-803.

11. Allaire JM, Crowley SM, Law HT, Chang SY, Ko HJ, Vallance BA. The intestinal epithelium: central coordinator of mucosal immunity. Trends Immunol 2018; 39: 677-96.

12. Pelaseyed T, Bergström JH, Gustafsson JK, et al. The mucus and mucins of the goblet cells and enterocytes provide the first defense line of the gastrointestinal tract and interact with the immune system. Immunol Rev 2014; 260: 8-20.

13. Liso M, De Santis S, Verna G, et al. A specific mutation in muc2 determines early dysbiosis in colitis-prone winnie mice. Inflamm Bowel Dis 2020; 26: 546-56.

14. Gillois K, Lévêque $M$, Théodorou V, Robert H, MercierBonin M. Mucus: an underestimated gut target for environmental pollutants and food additives. Microorganisms 2018; 6: 53.

15. Pelaseyed T, Hansson GC. Membrane mucins of the intestine at a glance. J Cell Sci 2020; 133: jcs240929. 
16. Węgrzyn D, Adamek K, Łoniewska B. Budowa bariery jelitowej. Pomeranian J Life Sci 2017; 63: 6-9.

17. Capaldo CT, Powell DN, Kalman D. Layered defense: how mucus and tight junctions seal the intestinal barrier J Mol Med 2017; 95: 927-34.

18. Johansson ME, Phillipson M, Petersson J, Velcich A, Holm L, Hansson GC. The inner of the two Muc2 mucin-dependent mucus layers in colon is devoid of bacteria. Proc Natl Acad Sci USA 2008; 105: 15064-9.

19. Parikh K, Antanaviciute A, Fawkner-Corbett D, et al. Colonic epithelial cell diversity in health and inflammatory bowel disease. Nature 2019; 567: 49-55.

20. Chen SJ, Liu XW, Liu JP, Yang XY, Lu FG. Ulcerative colitis as a polymicrobial infection characterized by sustained broken mucus barrier. World J Gastroenterol 2014; 20 9468-75.

21. Stange EF, Schroeder BO. Microbiota and mucosal defense in IBD: an update. Expert Rev Gastroenterol Hepatol 2019; 13: 963-76.

22. De la Fuente M, MacDonald TT, Hermoso MA. Intestinal homeostasis and disease: a complex partnership between immune cells, non-immune cells, and the microbiome. Front Immunol 2019; 10: 2775.

23. Marques R, Boneca IG. Expression and functional importance of innate immune receptors by intestinal epithelial cells. Cell Mol Life Sci 2011; 68: 3661-73.

24. Larabi A, Barnich N, Nguyen HTT. New insights into the interplay between autophagy, gut microbiota and inflammatory responses in IBD. Autophagy 2020; 16: 38-51.

25. Caer C, Wick MJ. Human intestinal mononuclear phagocytes in health and inflammatory bowel disease. Front Immunol 2020; 11: 410.

26. Garrett WS, Gordon J, Glimcher LH. Homeostasis and inflammation in the intestine. Cell 2010; 140: 859-70.

27. Błachowicz O, Zwolińska K. Rola genów kodujących immunoglobulinopodobne receptory komórek cytotoksycznych (KIR) oraz ich ligandy w podatności i przebiegu zakażenia HIV. Postepy Hig Med Dosw 2016; 70: 140923.

28. Dowds CM, Blumberg RS, Zeissig S. Control of intestinal homeostasis through crosstalk between natural killer T cells and the intestinal microbiota. Clin Immunol 2015; 159: 128-33.

29. Tigl H, Kaser A. Gut microbiome, obesity, and metabolic dysfunction. J Clin Invest 2011; 121: 2126-32.

30. Zhernakova A, Kurilshikov A, Bonder MJ, et al. Population-based metagenomics analysis reveals markers for gut microbiome composition and diversity. Science 2016; 352: 565-9.

31. D'Argenio V, Salvatore F. The role of the gut microbiome in the healthy adult status. Clin Chim Acta 2015; 451: 97-102.

32. Rudzki L, Frank M, Szulc A, Gałęcka M, Szachta P, Barwinek D. Od jelit do depresji - rola zaburzeń ciągłości bariery jelitowej następcza aktywacja układu immunologicznego w zapalnej hipotezie depresji. Neuropsychiatria i Neuropsychologia 2012; 7: 76-84.

33. Lin L, Zhang J. Role of intestinal microbiota and metabolites on gut homeostasis and human diseases. BMC Immunol 2017; 18: 2.

34. Meng X, Zhang G, Cao H, et al. Gut dysbacteriosis and intestinal disease: mechanism and treatment. J Appl Microbiol 2020; 129: 787-805.

35. Schultz BM, Paduro CA, Salazar GA, et al. A potential role of salmonella infection in the onset of inflammatory bowel diseases. Front Immunol 2017; 8: 191.
36. Swidsinski A, Loening-Baucke V, Theissig F, et al. Comparative study of the intestinal mucus barrier in normal and inflamed colon. Gut 2007; 56: 343-50.

37. Peterson CT, Sharma V, Elmén L, Peterson SN. Immune homeostasis, dysbiosis and therapeutic modulation of the gut microbiota. Clin Exp Immunol 2015; 179: 363-77.

38. Czajkowska A, Szponar B. Short chain fatty acids (SCFA), the products of gut bacteria metabolism and their role in the host. Postep Hig Med Dosw 2018; 72: 131-42.

39. Sun M, Wu W, Liu Z, Cong Y. Microbiota metabolite short chain fatty acids, GPCR, and inflammatory bowel diseases. J Gastroenterol 2017; 52: 1-8.

40. Zhang N, Ju Z, Zuo T. Time for food: the impact of diet on gut microbiota and human health. Nutrition 2018; 51-52: 80-5.

41. Panasiuk A, Kowalińska J. Mikrobiota przewodu pokarmowego. $1^{\text {st }}$ ed. PZWL, Warszawa 2020.

42. Gentile CL, Weir TL. The gut microbiota at the intersection of diet and human health. Science 2018; 362: 776-80.

43. Zeng MY, Inohara N, Nuñez G. Mechanisms of inflammation-driven bacterial dysbiosis in the gut. Mucosa Immunol 2017; 10: 18-26.

44. Chassaing B, Koren O, Goodrich JK, et al. Dietary emulsifiers impact the mouse gut microbiota promoting colitis and metabolic syndrome. Nature 2015; 519: 92-6.

45. Partridge D, Lloyd KA, Rhodes JM, Walker AW, Johnstone AM, Campbell BJ. Food additives: Assessing the impact of exposure to permitted emulsifiers on bowel and metabolic health - introducing the FADiets study. Nutr Bull 2019; 44: 329-49.

46. Pereira MT, Malik M, Nostro JA, Mahler GJ, Musselman LP. Effect of dietary additives on intestinal permeability in both Drosophila and a human cell co-culture. Dis Model Mech 2018; 11: dmm034520.

47. Hummel TZ, Kindermann A, Stokkers PC, Benninga MA ten Kate FJ. Exogenous pigment in Peyer patches of children suspected of having IBD. J Pediatr Gastroenterol Nutr 2014; 58: 477-80.

48. Urrutia-Ortega IM, Garduño-Balderas LG, DelgadoBuenrostro NL, et al. Food-grade titanium dioxide exposure exacerbates tumor formation in colitis associated cancer model. Food Chem Toxicol 2016; 93: 20-31.

49. Jimenez Loayza JJ, Berendsen EM, The JJ, et al. The common food additives sodium sulfite and polysorbate 80 have a profound inhibitory effect on the commensal, anti-inflammatory bacterium Faecalibacterium prausnitzii: the ENIGMA study. J Crohn's Colitis 2019; 13 Suppl 1: S542-3.

50. Martino JV, Van Limbergen J, Cahill LE. The role of carrageenan and carboxymethylcellulose in the development of intestinal inflammation. Front Pediatr 2017; 5: 96.

51. Borthakur A, Bhattacharyya S, Dudeja PK, Tobacman JK. Carrageenan induces interleukin-8 production through distinct Bcl10 pathway in normal human colonic epithelial cells. Am J Physiol Gastrointest Liver Physiol 2007; 292: G829-38.

52. Becker HM, Bertschinger MM, Rogler G. Microparticles and their impact on intestinal immunity. Dig Dis 2012; 30 Suppl 3: 47-54.

53. Bettini S, Boutet-Robinet E, Cartier C, et al. Food-grade $\mathrm{TiO} 2$ impairs intestinal and systemic immune homeostasis, initiates preneoplastic lesions and promotes aberrant crypt development in the rat colon. Sci Rep 2017; 7: 40373 .

54. Ruiz PA, Morón B, Becker HM, et al. Titanium dioxide nanoparticles exacerbate DSS-induced colitis: role of the NLRP3 inflammasome. Gut 2017; 66: 1216-24. 
55. Pinget $G$, Tan J, Janac B, et al. Impact of the food additive titanium dioxide (E171) on gut microbiota-host interaction. Front Nutr 2019; 6: 57.

56. Chen Z, Han S, Zhou D, Zhou S, Jia G. Effects of oral exposure to titanium dioxide nanoparticles on gut microbiota and gut-associated metabolism in vivo. Nanoscale 2019; 11: 22398-412.

57. Radziwill-Bienkowska JM, Talbot P, Kamphuis JBJ, et al. Toxicity of food-grade $\mathrm{TiO} 2$ to commensal intestinal and transient food-borne bacteria: new insights using nano-SIMS and synchrotron UV fluorescence imaging. Front Microbiol 2018; 9: 794.

58. Lock JY, Carlson TL, Wang CM, Chen A, Carrier RL. Acute exposure to commonly ingested emulsifiers alters intestinal mucus structure and transport properties. Sci Rep 2018; 8: 10008.

59. Laudisi F, Di Fusco D, Dinallo V, et al. The food additive maltodextrin promotes endoplasmic reticulum stress-driven mucus depletion and exacerbates intestinal inflammation. Cell Mol Gastroenterol Hepatol 2019; 7: 457-73.

60. Bhattacharyya S, Gill R, Chen ML, et al. Toll-like receptor 4 mediates induction of the Bcl10-NFkappaB-interleukin-8 inflammatory pathway by carrageenan in human intestinal epithelial cells. J Biol Chem 2008; 283 10550-8.

61. Rodriguez-Palacios A, Harding A, Menghini P, et al. The artificial sweetener splenda promotes gut proteobacteria, dysbiosis, and myeloperoxidase reactivity in Crohn's disease-like ileitis. Inflamm Bowel Dis 2018; 24: 1005-20.

62. Golonka RM, Yeoh BS, Vijay-Kumar M. Dietary additives and supplements revisited: the fewer, the safer for gut and liver health. Curr Pharmacol Rep 2019; 5: 303-16.

63. Santos PS, Caria CRP, Gotardo EMF, Ribeiro ML, Pedrazzoli JJ, Gambero A. Artificial sweetener saccharin disrupts intestinal epithelial cells' barrier function in vitro. Food Funct 2018; 9: 3815-22.

64. Rozporządzenie Parlamentu Europejskiego i Rady (WE) NR 1333/2008 z dnia 16 grudnia 2008 r. w sprawie dodatków do żywności. https://eur-lex.europa.eu/legalcontent/PL/TXT/PDF/?uri=CELEX:32008R1333\&from=pl (Accessed: 10.06.2020).

65. Krog N. Functions of emulsifiers in food systems. J Am Oil Chem Soc 1997; 54: 124-31.

66. Hu X, Karthik P, Chen J. Manipulating oral behaviour of food emulsions using different emulsifiers. J Food Sci Technol 2019; doi: 10.1111/ijfs.14152.

67. Viennois E, Chassaing B. First victim, later aggressor: How the intestinal microbiota drives the pro-inflammatory effects of dietary emulsifiers? Gut Microbes 2018; 9: 289-91.

68. Chassaing B, Van de Wiele T, De Bodt J, Marzorati M, Gewirtz AT. Dietary emulsifiers directly alter human microbiota composition and gene expression ex vivo potentiating intestinal inflammation. Gut 2017; 66: 1414-27.

69. Glade MJ, Meguid MM. Dietary emulsifiers, the human intestinal mucus and microbiome, and dietary fiber. Nutrition 2016; 32: 609-14.

70. Swidsinski A, Ung V, Sydora BC, et al. Bacterial overgrowth and inflammation of small intestine after carboxymethylcellulose ingestion in genetically susceptible mice. Inflamm Bowel Dis 2009; 15: 359-64.

71. Roca-Saavedra P, Mendez-Vilabrille V, Miranda JM, et al. Food additives, contaminants and other minor components: effects on human gut microbiota - a review. J Physiol Biochem 2018; 74: 69-83.

72. Roberts CL, Rushworth SL, Richman E, Rhodes JM. Hypothesis: Increased consumption of emulsifiers as an ex- planation for the rising incidence of Crohn's disease. J Crohns Colitis 2013; 7: 338-41.

73. Cani PD, Everard A. Keeping gut lining at bay: impact of emulsifiers. Trends Endocrinol Metab 2015; 26: 273-4.

74. Lewis JD, Abreu MT. Diet as a trigger or therapy for inflammatory bowel diseases. Gastroenterology 2017; 152: 398-414.e6.

75. Merga Y, Campbell BJ, Rhodes JM. Mucosal barrier, bacteria and inflammatory bowel disease: possibilities for therapy. Dig Dis 2014; 32: 475-83.

76. Swidsinski A, Loening-Baucke V, Herber A. Mucosal flora in Crohn's disease and ulcerative colitis - an overview. J Physiol Pharmacol 2009; 60 Suppl 6: 61-71.

77. Sigall-Boneh R, Levine A, Lomer M, et al. Research gaps in diet and nutrition in inflammatory bowel disease. A topical review by D-ECCO Working Group (Dietitians of ECCO). J Crohns Colitis 2017; 11: 1407-19.

78. Silva MM, Lidon FC. Food preservatives - an overview on applications and side effects. Emirates J Food Agriculture 2016; 28: 366-73.

79. Sharma S. Food preservatives and their harmful effects. International Journal of Scientific and Research Publications 2015; 5 .

80. Damas OM, Garces L, Abreu MT. Diet as adjunctive treatment for inflammatory bowel disease: review and update of the latest literature. Curr Treat Options Gastro 2019; 17: 313-25.

81. Hrncirova L, Machova V, Trckova E, Krejsek J, Hrncir T. Food preservatives induce proteobacteria dysbiosis in human-microbiota associated Nod2-deficient mice. Microorganisms 2019; 7: 383.

82. Hrncirova L, Hudcovic T, Sukova E, et al. Human gut microbes are susceptible to antimicrobial food additives in vitro. Folia Microbiol 2019; 64: 497-508.

83. Raposa B, Pónusz R, Gerencsér G, et al. Food additives: sodium benzoate, potassium sorbate, azorubine, and tartrazine modify the expression of NFאB, GADD $45 \alpha$, and MAPK8 genes. Physiol Int 2016; 103: 334-43.

84. Krzyśko-Łupicka T, Kręcidło $M$, Kręcidło $Ł$. Barwniki w żywności a zdrowie konsumentów. Kosmos. Probl Nauk Biol 2016; 65: 543-52.

85. McCann D, Barrett A, Cooper A, et al. Food additives and hyperactive behaviour in 3-year-old and 8/9-year-old children in the community: a randomised, double-blinded, placebo-controlled trial. Lancet 2007; 370: 1560-7.

86. Vojdani A, Vojdani C. Immune reactivity to food coloring. Altern Ther Health Med 2015; 21 Suppl 1: 52-62.

87. Zsila F, Kohut G, Beke-Somfai T. Disorder-to-helix conformational conversion of the human immunomodulatory peptide LL-37 induced by antiinflammatory drugs, food dyes and some metabolites. Int J Biol Macromol 2019; 129: $50-60$

88. Dafallah AA, Abdellah AM, Abdel-Rahim EA, Ahmed SH. Physiological effects of some artificial and natural food coloring on young male albino rats. J Food Technol Res 2015; 2: 21-32.

89. European Food Safety Authority. Re-evaluation of titanium dioxide (E 171) as a food additive. EFSA J 2016; 14: 4545 .

90. Sycheva LP, Zhurkov VS, Iurchenko VV, et al. Investigation of genotoxic and cytotoxic effects of micro- and nanosized titanium dioxide in six organs of mice in vivo. Mutat Res 2011; 726: 8-14.

91. Proquin H, Rodríguez-Ibarra C, Moonen CG, et al. Titanium dioxide food additive (E171) induces ROS formation and genotoxicity: contribution of micro and nanosized fractions. Mutagenesis 2017; 32: 139-49. 
92. Faust JJ, Doudrick K, Yang Y, Westerhoff P, Capco DG. Food grade titanium dioxide disrupts intestinal brush border microvilli in vitro independent of sedimentation. Cell Biol Toxicol 2014; 30: 169-88.

93. Tada-Oikawa S, Ichihara G, Fukatsu H, et al. Titanium dioxide particle type and concentration influence the inflammatory response in Caco-2 cells. Int J Mol Sci 2016; 17: 576.

94. Niedźwiedzka-Rystwej P, Deptuła W. Defensins: an important innate element of the immune system in mammals. Postep Hig Med Dosw 2008; 62: 524-9.

95. Hwang JS, Yu J, Kim HM, Oh JM, Choi SJ. Food additive titanium dioxide and its fate in commercial foods. Nanomaterials 2019; 9: 1175.

96. Guo Z, Martucci NJ, Moreno-Olivas F, Tako E, Mahler GJ. Titanium dioxide nanoparticle ingestion alters nutrient absorption in an in vitro model of the small intestine. Nanolmpact 2017; 5: 70-82.

97. Shahidi F, Ambigaipalan P. Phenolics and polyphenolics in foods, beverages and spices: antioxidant activity and health effects - a review. J Funct Foods 2015; 18: 820-97.

98. Pop A, Berce C, Bolfa P, et al. Evaluation of the possible endocrine disruptive effect of butylated hydrohyanisole, butylated hydroxytoluene and propyl gallate in immature female rats. Farmacia 2013; 61: 202-11.

99. Carocho M, Barreiro MF, Morales P, Ferreira I. Adding molecules to food, pros and cons: a review on synthetic and natural food additives. Compr Rev Food Sci Food Saf 2014; 13: 377-99.

100. Hamishehkar H, Khani S, Kashanian S, Ezzati Nazhad Dolatabadi J, Eskandani M. Geno- and cytotoxicity of propyl gallate food additive. Drug Chem Toxicol 2014; 37: 241-6.

101. Yang C, Lim W, Bazer FW, Song G. Propyl gallate induces cell death and inhibits invasion of human trophoblasts by blocking the AKT and mitogen-activated protein kinase pathways. Food Chem Toxicol 2017; 109: 497-504.

102. Holton KF, Taren DL, Thomson CA, Bennett RM, Jones KD. The effect of dietary glutamate on fibromyalgia and irritable bowel symptoms. Clin Exp Rheumatol 2012 30 (6 Suppl 74): 10-7.

103. Avuloglu-Yilmaz E, Yuzbasioglu D, Unal F. In vitro genotoxicity assessment of monopotassium glutamate and magnesium diglutamate. Toxicol In Vitro 2020; 65: 104780.

104. Zeng L, Hu S, Chen P, Wei W, Tan Y. Macronutrient intake and risk of Crohn's disease: systematic review and dose-response meta-analysis of epidemiological studies. Nutrients 2017; 9: 500.

105. Racine A, Carbonnel F, Chan SS, et al. Dietary patterns and risk of inflammatory bowel disease in Europe: results from the EPIC Study. Inflamm Bowel Dis 2016; 22: 345-54.

106. Wang YF, Ou-Yang Q, Xia B, et al. Multicenter casecontrol study of the risk factors for ulcerative colitis in China. World J Gastroenterol 2013; 19: 1827-33.

107. Wang F, Feng J, Gao Q, et al. Carbohydrate and protein intake and risk of ulcerative colitis: systematic review and dose-response meta-analysis of epidemiological studies. Clin Nutr 2017; 36: 1259-65.

108. Bueno Hernández N, MañeAlmero J, Cortes I, Yamamoto-Furusho JK. Role of nutrition in inflammatory bowel disease (IBD): new therapeutic approaches and recent outcomes. J Nutr Ther 2012; 1: 132-7.

109. Schiffman SS, Rother KI. Sucralose, a synthetic organochlorine sweetener: overview of biological issues. J Toxicol Environ Health B Crit Rev 2013; 16: 399-451.
110. Qin X. Etiology of inflammatory bowel disease: a unified hypothesis. World J Gastroenterol 2012; 18: 1708-22.

111. Rizzello F, Spisni E, Giovanardi E, et al. Implications of the westernized diet in the onset and progression of IBD. Nutrients 2019; 11: 1033.

112. Cox SR, Prince AC, Myers CE, et al. Fermentable carbohydrates (FODMAPs) exacerbate functional gastrointestinal symptoms in patients with inflammatory bowel disease: a randomised, double-blind, placebocontrolled, cross-over, re-challenge trial. J Crohns Colitis 2017; 11: 1420-9.

113. Laudisi F, Di Fusco D, Dinallo V, et al. Food preservatives and additives exacerbate intestinal inflammation. Abstracts of the $22^{\text {nd }}$ National Congress of Digestive Diseases; 2016. doi: 10.1016/S1590-8658(16)30107-4.

114. González-Bermúdez CA, López-Nicolás R, Peso-Echarri P Frontela-Saseta C, Martínez-Graciá C. Effects of different thickening agents on infant gut microbiota. Food Funct 2018; 9: 1768-78.

115. Zychnowska M, Onacik-Gür S, Krygier K. Właściwości i możliwości wykorzystania zamienników tłuszczów dostępnych na rynku. Probl Hig Epidemiol 2015; 96: 42-50. 